\title{
Ischemic preconditioning induces neuroprotection cause by a transient global ischemia via maintaining the expression of P63
}

\author{
JH Cho ${ }^{1 *}$, CW Park1, TG Ohk1, MC Shin ${ }^{1}$, YS Kim¹ ${ }^{1}$ MH Won ${ }^{2}$ \\ From ESICM LIVES 2015 \\ Berlin, Germany. 3-7 October 2015
}

\section{Introduction}

p63 is a transcription factor of p53 gene family, which are involved in development, differentiation and cell response to stress; however, their roles in ischemic preconditioning (IPC) in the brain are not clear.

\section{Objectives}

In the present study, we investigated the effect of IPC on p63 immunoreactivity caused by transient cerebral ischemia, which was induced by 5 min of transient ischemia, in gerbils, and IPC was induced by subjecting the gerbils to 2 min of ischemia followed by 1 day of recovery.

\section{Methods}

The animals were randomly assigned to 4 groups (shamoperated-group, ischemia-operated-group, IPC plus (+)-sham-operated-group and IPC+ischemia-operatedgroup).

\section{Results}

The number of viable neurons in the stratum pyramidale of the hippocampal CA1 region (CA1) was significantly increased by IPC+ischemia-operated-group compared with that in the ischemia-operated-group 5 days after ischemic insult. We found that strong p63 immunoreactivity was detected in the CA1 pyramidal neurons in the sham-operated-group, and the immunoreactivity was decreased with time after ischemia-reperfusion. In addition, strong p63 immunoreactivity was newly expressed in the microglial cells of the CA1 region from 2 days after ischemia-reperfusion. In all the IPC+sham-operated-group, p63 immunoreactivity in the CA1 pyramidal

${ }^{1}$ Kangwon National University, Emergency Medicine, Chuncheonsi, Korea, Republic of

Full list of author information is available at the end of the article neurons was similar to that in the sham-operated-group, and the immunoreactivity was well maintained in the IPC+ischemia-operated-groups after cerebral ischemia.

\section{Conclusions}

In brief, our present findings showed that IPC dramatically protected the reduction of p63 immunoreactivity in the pyramidal neurons of the CA1 region after ischemiareperfusion, and this result suggests that the expression of p63 may be necessary for the neurons to survive after transient cerebral ischemia.

\section{Authors' details}

${ }^{1}$ Kangwon National University, Emergency Medicine, Chuncheonsi, Korea, Republic of. ${ }^{2}$ Kangwon National University, Neurobiology, Chuncheonsi, Korea, Republic of.

Published: 1 October 2015

doi:10.1186/2197-425X-3-S1-A771

Cite this article as: Cho et al:: Ischemic preconditioning induces neuroprotection cause by a transient global ischemia via maintaining the expression of P63. Intensive Care Medicine Experimental 2015 3(Suppl 1):A771.

Submit your manuscript to a SpringerOpen ${ }^{\bullet}$ journal and benefit from:

- Convenient online submission

- Rigorous peer review

- Immediate publication on acceptance

- Open access: articles freely available online

- High visibility within the field

Retaining the copyright to your article

Submit your next manuscript at $>$ springeropen.com

\section{SpringerOpen $^{\odot}$}

(C) 2015 Cho et al.; This is an Open Access article distributed under the terms of the Creative Commons Attribution License (http:// creativecommons.org/licenses/by/4.0), which permits unrestricted use, distribution, and reproduction in any medium, provided the original work is properly cited. 